\title{
TINGKAT PENGETAHUAN PELATIH BOLA VOLI TENTANG PROGRAM LATIHAN MENTAL DI KABUPATEN SLEMAN YOGYAKARTA
}

\author{
Syamsuryadin, Ch. Fajar Sri Wahyuniati \\ Pendidikan Kepelatihan Olahraga FIK UNY, Yogyakarta \\ Email : syamsuryadinadek@gmail.com
}

\begin{abstract}
This study aimed to identify the level of knowledge regarding mental training program for athletes among volley ball coaches. It is a descriptive research using survey method. The subjects were all volley ball coaches in Sleman District who fit in the criteria, there were 16 coaches. Research result showed that the level of knowledge among volley ball coaches in Sleman District about mental training were: "very poor" by $6.25 \%$, "poor" by $18.75 \%$, "enough" by $43.75 \%$, "good" by $18.75 \%$ and "very good" by $12.5 \%$. The average value was 37.69 which indicated that the majority of volleyball coach's knowledge regarding mental training was moderate in Sleman District.
\end{abstract}

Keywords: metal training program, volley ball coach, level of knowledge.

\begin{abstract}
ABSTRAK
Penelitian ini bertujuan untuk mengidentifikasi tingkat pengetahuan pelatih bola voli tentang program latihan mental untuk atlet. Penelitian ini merupakan penelitian deskriptif dengan metode survey. Subyek penelitian ini adalah seluruh pelatih bola voli di Kabupaten Sleman yang sesuai kriteria sebanyak 16 orang. Hasil penelitian menunjukkan bahwa tingkat pengetahuan pelatih bola voli di Kabupaten Sleman tentang program latihan mental adalah sebagai berikut: berkategori "sangat kurang" sebesar 6,25\%, kategori "kurang" sebesar 18,75\%, kategori "cukup" sebesar 43,75\%, kategori "baik" sebesar 18,75\% dan kategori "sangat baik" sebesar 12,5\%. Nilai rata-rata yang dimiliki adalah 37,69 yang menunjukkan bahwa mayoritas pengetahuan pelatih bola voli tentang program latihan mental di Kabupaten Sleman berkategori sedang,
\end{abstract}

Kata kunci : program latihan mental, pelatih bola voli, tingkat pengetahuan.

\section{PENDAHULUAN}

Aspek mental merupakan aspek yang sangat penting yang dibutuhkan hampir di seluruh cabang olahraga. Untuk meningkatkan prestasi maksimal tidak hanya dibutuhkan kemampuan fisik, teknik, taktik, atau strategi, tetapi latihan mental memegang peranan penting untuk menghasilkan mental yang baik. Hal ini sesuai dengan pendapat
Rushall (Komarudin, 2013: 2) “mental skills training for sport is designed to produce psychology state and skills in athletes that will lead to perfor-mance enhacement”. Apabila dalam aspek tersebut terpenuhi oleh sebuah tim sudah bisa dipastikan prestasi akan bisa diraih, seperti yang dikatakan oleh Ibrahim (2008:112) "untuk meraih prestasi puncak sebagai suatu perwujudan aktualisasi diri bagi atlet, modal utama adalah harus 
memiliki kesehatan yang prima, baik fisik maupun mental, agar tercapai prestasi yang optimal". Apabila aspek teknik dan mental bisa terpenuhi maka prestasi pun pasti bisa didapatkan karena aspek teknik dan mental sangat berhubungan. Gunarsa (2008: 21) menyatakan, "kegiatan psikologi olahraga sudah banyak dilakukan di negara-negara yang sedang berkembang dalam aspek olahraga. Dari pendapat tersebut dapat disimpulkan bahwa latihan mental dapat meningkatkan prestasi yang optimal jika dilakukan dengan baik dan terprogram sehingga atlet yang dihasilkan memiliki kualitas yang baik.

Latihan mental merupakan unsur yang sangat penting hampir di seluruh cabang olahraga. Dengan demikian latihan mental perlu mendapat perhatian yang sangat penting untuk kesiapan mental atlet itu sendiri, pengembangan dan pemeliharaan mental tidak dapat dilakukan secara terpisah agar keseimbangan latihan teknik dan mental sejalan dengan program latihan. Latihan mental merupakan satu kesatuan yang utuh dari komponen-komponen yang tidak bisa terpisahkan.

Setelah melakukan survei di lapangan pada saat Mikro, PPL dan Magang, ternyata masih ada pelatih bola voli di Kabupaten Sleman yang belum memberikan latihan mental kepada atletnya. Latihan yang dilakukan cenderung ke arah latihan fisik dan teknik bola voli. Menurut hasil wawancara dengan atlet bola voli di Kabupaten Sleman, para atlet juga menyatakan memang belum mendapatkan metode latihan mental dari pelatih, sehingga pada saat menghadapi latihan yang berat maupun pertandingan mereka belum sepenuhnya siap. Meskipun atlet giat berlatih, namun atlet sering merasa kurang yakin terhadap kemampuan ataupun teknik yang dimiliki. Selain itu, atlet masih sering merasa kurang mampu bersaing dengan lawan yang memiliki kualitas satu level di atasnya dan kurang yakin bahwa dirinya mampu mengatasi tekanan baik saat latihan maupun pertandingan. Kondisi-kondisi yang dirasakan oleh atlet tersebut membuat penampilan tidak optimal baik pada saat latihan maupun pertandingan (wawancara dengan dengan tujuh atlet bola voli di Kabupaten Sleman, Mei 2015). Selain atlet, beberapa pelatih juga menyatakan belum pernah memberikan metode latihan mental kepada atletnya. Latihan yang dilakukan cenderung ke arah fisik dan teknik (wawancara dengan tiga orang pelatih Mei, 2015).

Memiliki mental yang tangguh, atlet perlu melakukan latihan mental yang sistematis, yang merupakan bagian tidak terpisahkan dari program latihan olahraga secara umum dan tertuang dalam perencanaan latihan tahunan atau periodesasi latihan. Seringkali dijumpai bahwa masalah mental atlet sesungguhnya bukan murni merupakan masalah psikologis, namun juga disebabkan oleh faktor teknis atau fisiologis. Contohnya: jika kemampuan atlet menurun karena faktor 
kesalahan teknik gerakan, maka persepsi atlet terhadap kemampuan dirinya juga akan berkurang. Jika masalah kesalahan gerak ini tidak teridentifikasi dan tidak segera diperbaiki, maka kesalahan gerak ini akan menetap. Akibatnya, kemampuan atlet tidak meningkat sehingga atlet menjadi kecewa dan lama kelamaan bisa menjadi frustasi bahkan memiliki pikiran dan sikap negatif terhadap prestasi olahraganya.

Latihan keterampilan psikologi dalam olahraga sangat penting dalam menunjang prestasi seorang atlet. Latihan keterampilan psikologi atau yang lebih dikenal dengan latihan mental merupakan salah satu program latihan wajib yang harus dijalani seorang atlet berdampingan dengan sesi latihan fisik, teknik, dan taktik. Aspek-aspek psikologis berupa struktur dan fungsi-fungsi kepribadian yang diselidiki dalam olahraga seperti: motivasi, emosi, kepercayaan diri, disiplin, ketegangan, kecemasan, agresifitas, pembinaan kelompok, dan interaksi sosial (Gunarsa, 2008: 21). Aspek-aspek tersebut memegang peranan penting untuk mencapai prestasi maksimal. Aspek-aspek psikologis tidak dengan sendirinya tumbuh dan berkembang dalam diri anak, tetapi aspek tersebut perlu dibina dan dikembangkan melalui teknik dan metode latihan keterampilan psikologis.

Psikologi memiliki peranan penting sesuai tujuan-tujuan tersebut. Terkait dengan tujuan eksplanatif, psikologi olahraga dapat memperdalam dan mengembangkan teori- teori yang berhubungan dengan tingkah laku dan pengalaman dalam olahraga, (misalnya timbulnya motivasi; terjadinya perubahan motivasi pada anak; stabilitas emosional; kematangan emosional; ketahanan mental dan latihan mental; masalah stress; masalah kecemasan; terjadinya frustrasi; upaya-upaya rileksasi; serta hubungannya dengan tindakan agresif dan sebagainya) (Gunarsa, 2008: 24).

Latihan mental dilakukan selama atlet menjalani latihan olahraga, karena seharusnya latihan mental merupakan bagian tidak terpisahkan dari program latihan atau periodesasi latihan. Latihan-latihan tersebut ada yang memerlukan waktu khusus (terutama saat-saat pertama mempelajari latihan relaksasi dan konsentrasi), namun pada umumnya tidak terikat oleh waktu sehingga dapat dilakukan kapan saja. Jika akan menerapkan latihan mental untuk mengatasi masalah mental psikologis, maka atlet, pelatih, maupun psikolog olahraga harus tahu pasti bahwa penyebab masalahnya adalah masalah mental (Satiadarma, 2000: $31)$.

Atas dasar pertimbangan latar belakang masalah di atas, maka penulis bermaksud untuk mengadakan penelitian tentang "Tingkat Pengetahuan Pelatih Bola Voli di Kabupaten Sleman mengenai Program Latihan Mental".

\section{METODE PENELITIAN}

\section{Jenis Penelitian}

Penelitian ini adalah penelitian deskriptif. Penelitian deskriptif adalah 
penelitian yang hanya menggambarkan keadaan ataustatus fenomena (Arikunto, 2006: 120). Metode yang digunakan dalam peneltian ini adalah metode survey dengan teknik pengumpulan data menggunakan tes.

\section{Subjek Penelitian}

Populasi dalam penelitian ini adalah seluruh pelatih bola voli di Kabupaten Sleman. Pengambilan sampel dalam penelitian ini dilakukan dengan purposive sampling. Menurut purposive sampling adalah teknik penentuan sampel dengan pertimbangan tertentu (Sugiyono, 2007: 85). Kriteria dalam penentuan sampel ini meliputi: (1) bersedia menjadi sampel, (2) pelatih bola voli di klub di Kabupaten Sleman, (3) pelatih yang masih aktif melatih di klub. Berdasarkan kriteria tersebut yang memenuhi berjumlah 16 pelatih.

\section{Instrumen dan Teknik Pengumpulan Data}

Dalam penelitian ini tes yang digunakan adalah soal pilihan ganda (multiple choice).

Tes pilihan ganda terdiri dari atas suatu keterangan atau pemberitahuan tentang suatu pengertian yang belum lengkap. Untuk melengkapinya harus memilih satu dari beberapa kemungkinan yang telah disediakan. Penilaian dalam instrumen tes pilihan ganda (multiple choice) pada penelitian ini adalah jika jawaban benar maka nilainya adalah 1 dan jika jawaban salah maka nilainya 0 .

\section{Uji Coba Instrumen}

Sebelum uji coba, peneliti melakukan validasi atau expert judgment. Uji coba dilakukan pada pelatih bola voli di klub Baja
78 Bantul yang berjumlah 9 orang. Berdasarkan hasil uji coba, menunjukkan bahwa terdapat 6 butir gugur, yaitu butir nomor 25, 33, 43, 45, 47, dan 52. Sehingga didapatkan 52 butir valid dan digunakan untuk penelitian. Berdasarkan hasil uji coba, menunjukkan bahwa instrument reliabel dengan koefisien reliabilitas sebesar 0,985.

\section{Teknik Analisis Data}

Setelah semua data terkumpul, langkahselanjutnya adalah menganalisis data sehingga data-data tersebut dapat ditarik suatu kesimpulan. Teknik analisis data dalam penelitian ini menggunakan teknik analisis data deskriptif kuantitatif. Cara perhitungan analisis data mencari besarnya frekuensi relative persentase, dengan rumus sebagai berikut:

$$
P=\frac{F}{N} \times 100 \%
$$

Keterangan:

$\mathrm{P}=$ Persentase yang dicari

$\mathrm{F}=$ Frekuensi

$\mathrm{N}=$ Jumlah Responden

(Sudijono, 2006)

\section{HASIL PENELITIAN DAN PEMBAHASAN}

\section{Hasil Penelitian}

Tingkat pengetahuan pelatih bola voli di Kabupaten Sleman terhadap program latihan mental diungkapkan dengan tes pilihan ganda yang berjumlah 52 butir. Setelah data penelitian terkumpul dilakukan analisis dengan menggunakan bantuan komputer program SPSS versi 16.0 for windows. 
Dari analisis data tingkat pengetahuan pelatih bola voli di Kabupaten Sleman terhadap program latihan mental diperoleh skor terendah (minimum) 34, skor tertinggi (maksimum) 41,0, rerata (mean) 37,69, nilai tengah (median) 38,0, nilai yang sering muncul (mode) 38,0, standar deviasi (SD) 1,92. Apabila ditampilkan dalam grafik, pada gambar 1 sebagai berikut:

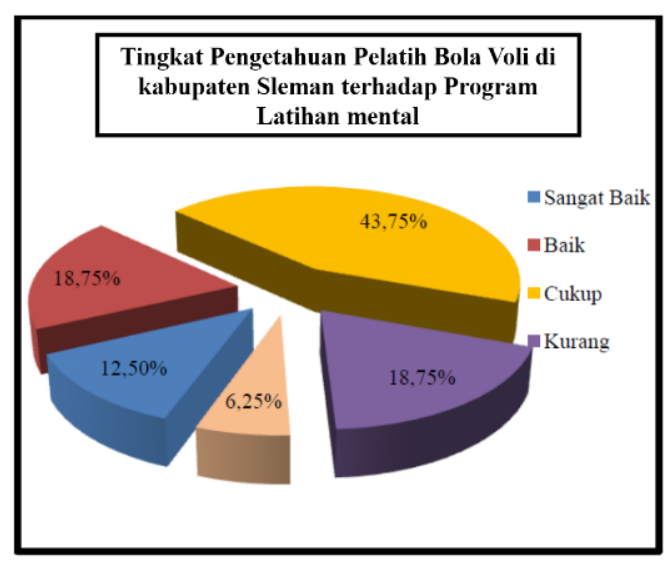

Gambar 1. Diagram Pie Tingkat Pemahaman Pelatih Bola Voli di Kabupaten Sleman terhadap Program Latihan Mental

Berdasarkan gambar 1 di atas, menunjukkan bahwa tingkat pengetahuan pelatih bola voli di Kabupaten Sleman terhadap program latihan mental berada pada kategori "sangat kurang" sebesar 6,25\% (1 orang), kategori "kurang” sebesar 18,75\% (3 orang), kategori “cukup" sebesar 43,75\% (7 orang), kategori "baik" sebesar 18,75\% (3 orang), dan kategori "sangat baik" sebesar $12,5 \%$ (2 orang). Berdasarkan nilai rata-rata yaitu 37,69 , tingkat pengetahuan pelatih bola voli di Kabupaten Sleman terhadap program latihan mental masuk dalam kategori "sedang".

\section{Pembahasan}

Penelitian ini bertujuan untuk mengetahui tingkat pengetahuan pelatih bola voli di Kabupaten Sleman terhadap program latihan mental. Berdasarkan hasil analisis menunjukkan bahwa tingkat pengetahuan pelatih bola voli di Kabupaten Sleman terhadap program latihan mental masuk dalam kategori "cukup". Hasil penelitian didapatkan pengetahuan pelatih bola voli di Kabupaten Sleman paling besar pada kategori cukup, yaitu sebesar $75 \%$ (12 pelatih), artinya pelatih sudah cukup mengetahui tentang program latihan mental. Namun dalam aplikasinya pelatih masih kurang menerapkan program latihan mental dalam latihan. Program latihan mental dalam penelitian ini terdiri atas pengertian latihan mental, tahap-tahap latihan mental, bentuk-bentuk latihan mental, dan ruang lingkup latihan mental. Program latihan tidak hanya bersifat fisik, namun latihan mental juga perlu diterapkan untuk mencapai prestasi maksimal dalam olahraga. Peningkatan kemampuan fisik, teknik dan taktik tanpa diberikan latihan mental yang baik akan mengakibatkan hasil negatif. Mental merupakan daya penggerak dan mendorong untuk menyempurnakan kemampuan fisik, teknik, dan atlet dalam penampilan olahraga. Setiap kali menghadapi suatu pertandingan mental atlet harus dipersiapkan, siap menghadapi rangsanganrangsangan emosional, siap menghadapi tugas yang berat, atau siap menghadapi beban mental. Peranan latihan mental di samping 
untuk menyiapkan mental atlet menjelang pertandingan, juga ditujukan untuk membina daya tahan mental atlet. Daya tahan mental

mental merupakan kondisi kejiwaan yang mengandung kesanggupan untuk mengembangkan kemampuan menghadapi gangguan, ancaman dalam keadaan bagaimanapun juga, baik yang datang dari dalam dirinya maupun dari luar dri atlet. Daya tahan mental perlu dimiliki atlet, agar atlet dapat menghadapi situasi-situasi kritis dalam pertandingan dengan penuh kepercayaan pada diri sendiri, dapat menguasai, dapat mengontrol permainannya, tetap tenang

khususnya saat menghadapi kemungkinan kekalahan, agar dapat bangkit untuk berpenampilan baik. Program latihan mental adalah gambaran dalam pikiran seseorang memiliki hal yang nyata dan mampu menciptakan kenyataan (realitas) sendiri dengan gambaran atau bayangan mental (mental imagines). Dalam hal ini bagaimana melihat dirinya dan kemampuannya, apakah secara positif dan negatif. Jika seseorang mengikuti suatu kejuaraan maka perasaan takut, tidak percaya diri atau perasaan tidak menentu tentang dirinya, dan perasaan tegang akan dapat dirasakan.

Latihan mental harus dilakukan dengan dedikasi dan disiplin yang tinggi. Secara umum persiapan mental yang dilakukan, berpedoman pada: kepercayaan penuh dalam dirinya dan kemampuan fisiknya; konsentrasi penuh dan memusatkan selama kompetisi; visualisasi penampilannya selama berhari-hari atau beberapa minggu sebelum pelaksanaan pertandingan (kompetisi); menganalisis berbagai kekurangan dan berusaha untuk memperbaiki penampilan dan teknik dan strategi; kemampuan untuk mengalahkan dengan mudah dan melihat kedepan pada tantangan-tantangan baru pada pertandingan berikutnya; tidak pernah melihat diri sendiri sebagai atlet yang kalah sekali atau dua kali dalam pertandingan.

Menyiapkan atlet agar matang menghadapi pertandingan perlu dilakukansedini mungkin, melalui prosedur dan proses latihan mental yang sistematik dan memakan waktu cukup panjang. Latihan mental dalam upaya membina mental atlet harus didasarkan pada falsafah bahwa Pelatih pada hakekatnya membantu perkembangan atlet, memperlakukan atlet sebagai subyek sehingga pada akhirnya atlet dapat mengembangkan dirinya sendiri. Tindakan overprotection akan mengakibatkan atlet justru tidak tahan menghadapi gangguangangguan emosional dan hambatan-hambatan beban mental lainnya. Peranan latihan mental dalam bola voli sangat penting diberikan kepada atlet, sehingga hambatan-hambatan yang dialami atlet baik yang datang dirinya atau lingkungan sekitar pada saat pertandingan dapat diatasai dengan baik oleh atlet. 


\section{KESIMPULAN}

Berdasarkan hasil analisis data dan pembahasan, dapat diambil kesimpulan, bahwa tingkat penngetahuan pelatih bola voli di Kabupaten Sleman terhadap program latihan mental berada pada kategori "cukup" sebesar 43,75\% (7 orang), kategori "baik" sebesar 18,75\%), kategori "kurang" sebesar 18,75\% (3 orang), dan kategori "sangat baik" sebesar 12,5\% (2 orang), "sangat kurang" sebesar $6,25 \%$ (1 orang).

Berdasarkan nilai rata-rata yaitu 37,69 , tingkat pengetahuan pelatih bola voli di Kabupaten Sleman terhadap program latihan mental masuk dalam kategori "sedang".

\section{SARAN}

Ada beberapa saran yang perlu disampaikan sehubungan dengan hasil penelitian ini, antara lain:

1. Agar mengembangkan penelitian lebih dalam lagi tentang tingkat pengetahuan pelatih bola voli di Kabupaten Sleman terhadap program latihan mental.

2. Agar melakukan penelitian tentang tingkat pengetahuan pelatih bola voli di Kabupaten Sleman terhadap program latihan mental dengan menggunakan metode lain.

\section{DAFTAR PUSTAKA}

Arikunto, Suharsimi. 2006. Prosedur Jakarta: Rineka Cipta.

\section{Penelitian Suatu Pendekatan Praktek.}

Gunarsa, Singgih. 2008. Psikologi Olahraga Prestasi. Jakarta: PT BPK Gunung Mulia.

Ibrahim. 2008. Perencanaan Pengajaran. Jakarta: Rineka Cipta.

Komarudin. 2013. Psikologi Olahraga Latihan Mental dalam Olahraga Kompetitif. Bandung: Remaja Rosdakarya.

Satiadarma, P.Monty. 2000. Dasar-dasar psikologi olahraga. Jakarta. Pustaka Sinar Harapan.

Sudijono, Anas. 2006. Pengantar Statistik Pendidikan. Jakarta: PT Grafindo Persada.

Sugiyono. 2007. Metode Penelitian Kuantitatif Kualitatif dan $R$ \& $D$. Bandung:

Alfabeta. 